\title{
The Role of Amateur Observatories in Falak Education in Malaysia
}

\author{
Ibnor Azli Ibrahim \\ Universiti Kebangsaan Malaysia \\ Email: iabi@ukm.edu.my \\ Mohd Hafiz Safiai \\ Universiti Kebangsaan Malaysia \\ Email: hafizsafiai@gmail.com
}

\section{Doi:10.5901/mjss.2014.v5n29p40}

\section{Abstract}

This article discusses the history and role of amateur observatories in Malaysia. To date, there are eight official observatories in Malaysia, excluding hilal sighting stations and amateur observatories. Nonetheless, studies on observatory, especially on amateur ones, are limited. Therefore, this study is undertaken to take a closer look at the history of amateur observatory development in Malaysia. In addition, this article also discusses the role that amateur observatories play in the aspect of falak education in Malaysia. This study completely used a qualitative approach based on primary and secondary sources via the method of document analysis, interviews and observation. Results found that there are several amateur observatories which are privately built in Malaysia, among which are Dr. Rowi's Mini Observatory and Shahgazer Observatory. Both observatories are owned by amateur falak enthusiasts and play the role as a venue for falak education, especially in the field of astrophotography. Indirectly, the existence of amateur observatories can help the advancement of the science of falak in Malaysia, simultaneously re-living the glory of Islamic civilization.

Keywords: amateur observatory; dr. rowi; shahgazer; astrophotography;

\section{Introduction}

Malaysia is one of the pioneer countries to the effort of building observatory. Observatories are built to fulfil the requirement of the Muslim community in matters concerning astronomy (falak), especially in affairs of worship such as determining the starting date of the Hiji months and calculating the time of prayers (Newcomb, 1881, p. 377; Lattis, 2011, p. 146 \& Ibrahim, Ahmad, Safiai \& Mujani, 2012, p. 1370). In addition, observatories also function as a place to do research such as studies on crescent (hilal) visibility, sunrise and prayer times. Moreover, education is one of the aspects given much emphasis in Islam (Hassan, Abiddin \& Ahmad, 2011). Therefore, observatories also function as centers for falak education where courses, seminars, 'astronomy days' and other activities are organized. Safiai, Jamsari and Ibrahim (2014) opined that Malaysia is seen to have the potential to penetrate the astro-tourism market through the construction of hotels at observatories. Through the building of hotels, staying visitors are offered astronomic observation session packages in order to give exposure of the science of falak to the public (Ibrahim, Ahmad \& Safiai, 2013). Nevertheless, a lack of literature concerning observatories in Malaysia warrants this study to be carried out. It cannot be denied that there are several articles about observatories, but the discussion within them on the history and importance of observatories are brief and limited. Hence, studies such as this one should be done considering that there are quite a number of observatories built in Malaysia, be it official ones or private.

This study commences on a review of past literatures in Malaysia such as 'The importance of observatory in astronomic research' by Othman (1993), 'Al-Khawarizmi Falak Complex: Planning and Future Direction' by Bahali (2006), 'Observatory technology: Then until Now' by Aziz (2010), 'The role of observatory institutions in the development of Islamic Civilization: A Highlight' by Ismail et al. (2008) and 'Future Direction of Observatories in Malaysia' by Zainuddin (2010). In truth, discussion on observatories presented in all of those studies was done briefly and limited to official observatories only. A lack of studies on amateur observatory warrants the conduct of a study such as this one. In addition, this study has referred to several previous works on amateur observatories undertaken at the international level such as 'The Work of An Astronomical Society' by Holden (1889), 'Work for the Amateur Astronomer' by Hale (1916), 'The Ultimate Location for Amateur Astronomy?' by Peach (2004) and 'An Innovative Alt-Alt Telescope for Small 
Observatories and Amateur Astronomers' by Riva, Basso and Canestrari (2012). Results of scrutiny of those works find that foreign countries, especially in Europe, conducted quite a number of studies on amateur observatories and this highlights the rapid growth of amateur observatories in the West. Hence, the objective of this research is to look closely the history of amateur observatory development in Malaysia and its role from the aspect of falak education.

After scrutiny, it seems that the number of studies which chronicle amateur observatories in Malaysia in a chronological, whole and in-depth manner is lacking. Therefore, a study on this is proper and timely to add information and at the same time give awareness and exposure to the community on the importance of amateur observatory. Moreover, this study can indirectly promote cooperation between professional and amateur astronomers in further advancing the cause of falak knowledge in Malaysia. Therefore, this study attempts to analyze and highlight the history and role of amateur observatories in Malaysia.

\section{The History of Amateur Observatories in Malaysia}

At the early stage, hilal sighting activities in Malaysia were only done by the experts in the field of Islamic religion such as the Islamic scholars (ulema), qadhi and mufti because they are knowledgeable in the discipline of falak and issues related to the affairs of daily worship of the Muslims. Hilal observation activities had been carried out even before Malaysian independence, as recorded in 1934 on the minaret of the Sultan Abu Bakar Mosque, Johor Bahru by Dato' Syed Alwe Tahir al-Hadad, the former Mufti of the State of Johore (Unit Falak Bahagian Penyelidikan, 2001, p. 11-12). Before 1972, matters for determining the start of the month of Ramadhan, Eid-ul-Fitri and Eid-ul-Adha are subject to state powers. Traditionally, hilal observation activities were done on hilltops and mosque minarets using simple equipment such as telescopes since they are easy to carry and use (Majlis Raja-Raja, 2010). According to Idris (2012), there was no construction of a specific building for observatory during that time and observation activities were done on high grounds wherever it was deemed suitable. On top of that, the path leading to observation sites could only be tracked on foot and no type of vehicle, not even motorcycles, could use the track. Normally, the observer would have to walk and climb the hill to reach the observation site. Idris (2012) added that limited technological capability was one of the problems often befalling the observers. Limited communication system capability made hilal observation activities not a smooth operation. For instance, result of observation had to be sent manually to the State Mufti departments from one village to another by a group of assigned task force.

Limitation in the available technology also caused difficulties to obtain results of hilal observation from each of the states because of the long duration it took to confirm the result of hilal being sighted or not. Because of that, various problems arose bringing about inconvenience to the Muslim community to the point that Malaysia was once shocked by the news that there was a state which celebrated Eid day one day earlier than the other states. Hence, the Council of Malay Rulers in its $92^{\text {nd }}$ conference on the $15^{\text {th }}$ and $16^{\text {th }}$ of March 1972 decreed that setting the start day of Ramadhan, the days Eid-ul-Fitri and Eid-ul-Adha were to be standardized throughout Malaysia (Majis Raja-raja, 2010). This standardization was an initiative mooted by the government to avoid a recurrence of the problem. The first official hilal sighting activity to determine the start of fasting for the whole of Malaysia was done on the $7^{\text {th }}$ of October 1972 corresponding to $29^{\text {th }}$ of Sha'ban $1392 \mathrm{H}$ in Teluk Kemang, Negeri Sembilan. Teluk Kemang was chosen to be the location for hilal sighting station indirectly making it the first official hilal sighting station in Malaysia. Since that moment, declaration of the start of Ramadhan, Eid-ul-Fitri and Eid-ul-Adha has been announced by the Keeper of the Ruler's Seal via radio and television. The announcement is done soon after a royal consent is granted by His Majesty the Seri Paduka Baginda Yang di-Pertuan Agong and the Malay Rulers (Majlis Raja-raja, 2010).

As discussed earlier on, it is commonly known that there was no construction of specific observatory buildings but there were sites for hilal observations. These sites were built to fulfil the daily worship requirement of the Muslims in Malaysia such as calculation of prayer times and determination of Eid day. No special equipment was readied at these stations except for a small shed which functioned as shelters from rain and heat of the sun. Observation instruments such as theodolite, telescope and binoculars had to be carried by the observers to the stations. However, this difficulty did not curb the observers from carrying out their task of obtaining an accurate result of hilal sighting. In tandem with the rapid progress and development in Malaysia, observation stations are now equipped with various facilities such as viewing balcony, mounting for observation equipment, restrooms and prayer rooms. This gives comfort and convenience to the observers and indirectly facilitates their observation activities and help in getting a more accurate and higher quality observation outcome. Various efforts have been made to enhance the stations through upgrading and adding more infrastructures at the observation stations. Consequently, observation stations have undergone an improvement in quality and development as seen today. Up to date, the number of hilal observation stations in Malaysia has increased to 30 , with each state having at least one official hilal sighting site. 
Amateur observatories existed even before Independence. Observatories are built throughout Malaysia, either on minarets of mosques, schools or even at home. However, most of amateur observatories in Malaysia are built at home. They are owned by a group of amateur astronomers or astronomy enthusiasts who study, observe and appreciate the marvel of creations and phenomena in the universe based on their own initiatives and keen interest. Quoting the words of Groombridge from the Royal Astronomical Society by Holden (1889, p. 10-11):

\begin{abstract}
Owing to the great perfection which the construction of optical instruments has attained in England, and the taste for scientific research universally prevalent, there have arisen in various parts of the kingdom a number of private and public observatories, in which the celestial phenomena are watched, and registered with assiduity and accuracy, by men whose leisure and talents peculiarly adapt them for such pursuits; while others, with a less splendid establishment, but by the sacrifice of more valuable time, pursue the same end with equal zeal and perseverance.
\end{abstract}

This is different from the scenario in the field of astronomy in Malaysia where amateur astronomers are often viewed as a group of unserious researchers who contribute virtually nothing. In reality the opposite is true. If viewed from the angle of technological know-how literacy, the group is quicker to adapt to the advancement in astronomy instrumentation. Even though the use of telescope in private observatories is not as impressive as in professional ones, it is however capable of giving good outcome, apart from the components being used efficiently (Hale, 1916, p. 53-54; Ford, 2011, p. 341). Observatory nowadays is no longer a privilege for the professional astronomers. In fact, amateur groups can afford to own it. Because of keen interest in astronomy, the amateur groups are willing to spend, even at a costly expense, to build and own an observatory to realize their dream. The cost of construction of these privately owned observatories are borne by the group themselves. These amateurs used the observatory to carry out personal observation at home without having to go to other existing observatory.

Indeed the construction of amateur observatories will facilitate sky surveillance activities of these amateur astronomers because usually the process of setting up and preparing the telescope may require a long time. Every observer must go through several steps or procedures prior to using their telescope. One of the steps is to align the telescope fixing to face true north (Luna, Zazueta \& Gutierrez, 2001, p. 379). The aligning process is actually not easy even with the help of a computer system. Moreover, this procedure must be done every time if the telescope is not fixed at a certain position. This problem can be avoided if the telescope is fixed at one place as done by these amateurs at their private observatories. Apart from that, building private observatory can reduce the physical effort to carry out observation activities. The amateur astronomer needs not to lift and carry the telescope around and other equipment such as cameras and binoculars as well as documents can be kept well and in order. Besides, the probability of the equipment to break can be lessened especially in the case of bad weather such as heavy rain and strong wind (Von Engelhardt, 1887, p. 502; Peach, 2004, p. 191). Other typical facilities at these observatories include viewing balcony, toilets and prayer room.

New astronomical findings such as planets outside the solar system, new comets, and earth crossing asteroids are only a few of findings discovered by the amateur group. These findings more or less help in the development of falak discipline in Malaysia. Each discovery by the amateur astronomers is studied in more detail by the professionals. Such discoveries are unlikely achievable without the combination of knowledge and skills covering optical technology, astronomy software, database, integration system, image processing, amateur-professional collaboration and others (Bowler, 2011, p. 26; Moore, 2009, p. 289). In Malaysia, the level of astronomy literacy of the society is still low and lagging behind other nations due to a lack of exposure at a young age. Moreover, the subject of astronomy is also viewed in general from a narrow perspective and the process of its advancement takes place at a slow pace. Through the medium of amateur observatory, amateur astronomers have a huge role to play in disseminating useful information on astronomy and preparing a simple and acceptable method for the public. There are two well-known amateur observatories in Malaysia, namely:

\title{
2.1 Dr. Rowi's Mini Observatory
}

Dr. Rowi's Mini Observatory is a personal observatory privately owned by Dr. Rowi whose real name is Mahamarowi bin Omar. He is a medical lecturer at the Anaesthesiology Department, Centre for Medical Science Studies, Hospital Universiti Sains Malaysia (HUSM) Kubang Kerian, Kelantan. He is also a consultant anaesthetist at the intensive care unit of HUSM. Realising that the universe is very much less explored, Dr. Rowi set his mind on learning and deepening his knowledge in science particularly astronomy. Even though he is a medical doctor, his profession does not deter him from spreading the science of astronomy to the society especially among students (Omar, 2006, p. 1). Because of 
interest in astronomy since an early age, he now successfully own and operate his own observatory. The observatory was built in 1998 at a cost of about RM10,000 (Observatori Negara Langkawi, 2009: 59-60). The observatory is built at his house at Lot 1400, Taman Tarbiyah, Guchil Bayam, Kota Bharu, Kelantan. The location coordinates of the observatory are latitude $6^{\circ} 06^{\prime} \mathrm{N}$ and longitude $102^{\circ} 16^{\prime} \mathrm{E}$. It is on the upper floor of the house at $5 \mathrm{~m}$ above sea level (Omar, 2012a).

By renovating the upper floor of the house, Dr. Rowi made it a place for observation activities (see Appendix A). The renovation includes making the roof retractable. The sliding roof was designed to be a roll-off roof system and made from heat resistant aluminum. The cost of building that was cheaper than building a dome. Roof renovation is important for the smooth operation of observation activities and at the same time it functions to protect the astronomic instruments underneath it in the observatory (see Appendix B). The renovation was important as the equipment at the observatory are expensive and need elaborate care (Observatori Negara Langkawi, 2009, p. 60). According to Hicks (2009, p. 2-3), there are advantages and disadvantages in changing the roof into the roll-off roof system for astronomic surveillance. One advantage is that equipment and tools will be more stable to use and less hot due to the effect of the cool environment. However, one drawback is that the space is more open and exposed during the observation activity. This disadvantage may result in noise and light pollution from the surrounding which may disrupt the observer's focus and comfort. The equipment and tools available at the observatory are listed in Table 1 below.

Table 1. Instruments in Dr. Rowi's Mini Observatory

\begin{tabular}{ll}
\hline Item & Model \\
\hline Observatory telescope & Meade LX200 12" \\
& Meade LX200 8" \\
& APM $115 \mathrm{~mm}$ Refractor AP F/7 \\
& Pentax $100 \mathrm{~mm}$ F/4 \\
& Pentax $75 \mathrm{~mm}$ SDHF F/6.7 \\
& Newlon Takahashi 10" \\
& Takahashi $67 \mathrm{~mm}$ \\
Portable telescope & Takahashi NJP (GEM) \\
& Takahashi EM 200 (GEM) \\
Mount & Orion Sky View pro \\
& LX 200 Meade Telescoper 12" \\
& SBIG ST-7XME + CFW-8A, SBIG 237A- Autoguider \\
& SBIG 2000 XCMI, Starlight Express Monochrome SXV-H9 \\
CCD camera & Starlight Express Monochrome MX 716 \\
& Starlight Express Single Shot Colour MX5-C \\
& Skynyx camera 2-1 monochrome \\
& Orion Star shoot-Planetary Imager \& Autoguider \\
& Maxim, CCDsoft, CCDOP, Nebulousity \& Adobe Photoshop \\
& The Sky 6, Starry Night Pro, Sky Map Pro \& The Tracker \\
\hline
\end{tabular}

Dr. Rowi's Mini Observatory is also equipped with a few other telescopes and sophisticated equipment, all of which were purchased by the Dr. Rowi himself. The equiment were bought gradually and not at once (Omar, 2009).

\subsection{ShahGazer Observatory (SGO)}

Shahgazer Observatory is a private observatory owned by Mr. Shahrin bin Ahmad. He graduated in 1998 with a computing degree from Universiti Putra Malaysia. Before setting up his own company, he served a number of information technology companies and was once involved in the Telekom Malaysia (TM) integration project. While serving the Telekom Malaysia Research and Development Division (TMR\&D), he managed several research projects, among which was a development of M\&E (Mechanical \& Electrical) automation system at the TM Tower. In addition, he was also involved in the installation work of a 24-inch telescope system at the Al-Khawarizmi Falak Complex, Malacca while working at Astronautic Technology Sdn. Bhd. Mr. Sharin bin Ahmad now owns a company, Equatorial Sky Innovations Sdn. Bhd., which focuses on developmental work on high technology systems and research in observatory automation systems (Ahmad, 2012a).

Mr. Shahrin bin Ahmad has a vast experience in the field of astronomy be it local or abroad. His valuable experience includes a series of observation expedition programs and recording of full solar eclipse in Turkey in 2006 and 
Indonesia and China in 2009 (Aziz, 2011). On top of that, he is often invited to give talks on astronomy organized by local universities, local communities, schools, local observatories, State Mufti Departments, National Space Agency and other agencies. Since 1997 until recently, he has handled more than 130 talks and night sky gazing activities. In addition, he is a consultant for a number of projects on astronomy education portals and the proud owner of the Malaysian online community of astronomy enthusiasts namely Falak Online (Ahmad, 2012a). Inspired by the success of Dr. Rowi's Mini Observatory, he took the step to build his private observatory at his house located in Sri Damansara, Kuala Lumpur. The observatory which is known as ShahGazer Observatory (SGO) is built on the rooftop of his house to follow the specifications suitable for astrophotography activities (Ahmad, 2011). The observatory began to fully operate in February 2011 where he does observation and astrophotography almost on a nightly basis depending on the suitability of the environment conditions (Ahmad, 2012a).

Since Mr. Shahrin bin Ahmad took Dr. Rowi's Mini Observatory as an inspiration, the design of SGO is much influenced by the observatory model. Renovation of the roof turning it into a roll-off-roof system (see Appendix D) made observation activities at the observatory easier to conduct (Hadi, 2011). According to him (2012b), he did not want to build a dome on purpose, feeling that it was not suitable with the condition of the house area and it would only disrupt the recorded images. Furthermore, SGO is fully operational to fulfil the requirements of astrophotography and research on astronomy instrumentation automation. Therefore, the equipment used is sophisticated and of high quality (see Appendix E). The list of instruments available at the observatory is in Table 2 below (Ahmad, 2011).

Table 2. Instruments in ShahGazer Observatory

\begin{tabular}{ll}
\hline Item & Model \\
\hline Telescope & Skywatcher Equinox 120ED f/7.5 Aperture: 120mm Focal Length: 900mm \\
& Skywatcher Equinox 80ED \\
& Skywatcher 80mm Refractor \\
& Vixen 8" VC200L \\
Mount & EQ6-Pro \& HEQ5 \\
CCD Camera & QHY9-mono \& QHY5-mono \\
Software & Moonlite Focuser, EQDIR \& GPUSB \\
\hline
\end{tabular}

\section{Activities at Amateur Observatory}

Throughout its operation, various activities have been organized at Dr. Rowi's Mini Observatory either by himself or together with a group or astronomical society who came to the observatory. The activities include observation and image capture using Charge-Coupled Device (CCD) camera which he does almost on a daily basis (Omar, 2012b). CCD camera is very crucial in observation exercise to record and take pictures of the observed objects and universal phenomena. Its capability and significance make it an important tool especially in astrophotography. On top of that, its capability can maximize light entering it without disturbing the focus on observed object to give better and higher quality images (Stuart, 2006: 1-2; Vasiliev \& Tataridou, 2013). Dr. Rowi is active in doing solar observation to get the latest images on sunspots and sun prominence (filament) (see Appendix C). In addition, Dr. Rowi's observatory is also made a venue for staff of government departments to undergo practical training in operating astronomic equipment such as telescope and to learn the basics in astronomic imaging techniques or astrophotography (Observatori Negara Langkawi, 2009, p. 62). Furthermore, astronomic surveillance activities for the public and student groups, especially around Kota Bharu, are also held (see Appendix C). Typically, all the activities are organized during school holidays or during certain astronomic phenomena such as solar and lunar eclipses, meteor showers and crescent moon (Observatori Negara Langkawi, 2009, p. 62).

Mr. Shahrin bin Ahmad is famous for his active involvement in the field of astronomy and is a freelance speaker involved in many observation activities locally and abroad. In addition, he is also often invited to give talks on astronomy throughout the country. Even though he is busy with outside activities, he also holds activities at his own observatory. Among the activities carried out at his observatory is astrophotography, taking pictures of deep sky objects such as stars, nebulae and galaxies apart from solar system objects such as the sun, planets and their moons (see Appendix F). In addition, he also records and processes astronomic phenomena images such as planet transit, solar eclipse and lunar eclipse. The pictures are private collection of which some are displayed on his website portal Falak Online. Like Dr. Rowi, Mr. Shahrin bin Ahmad also does observation and daily data collection on sunspots and sun prominence at the observatory (Ahmad, 2011). 
Due to his expertise in automation, he used that advantage to share his knowledge and experience through the activities at his observatory. According to Groover (2007: 5), automation system is capable of controlling a process either with or without human intervention to start, align, identify and measure process variables as well as stop a process in getting the required results. In general, this system is applied to increase production, improve its quality and control expenditure costs. Mr. Shahrin bin Ahmad has carried out studies in automation of an integrated observatory system using the Astronomy Common Object Model (ASCOM) utility at his observatory. Using this automation system which employs the ASCOM utility, he is able to automatically control his equipment via a computer. This system facilitates his work in tracking, observing and processing images of the required sky objects. He also receives visits by astronomy enthusiasts from schools, universities and government bodies as well as private companies who visit his observatory (see Appendix F). Through the visits, he can share and give exposure to the public on the activities he has been carrying out and at the same time introduce the existence of amateur observatories in Malaysia (Ahmad, 2011).

\section{Conclusion}

Astronomy is a wide branch of knowledge and can be delved into by anyone who is interested. However, it must be guided in the right direction. Amateur astronomers should take the opportunity to play a role in contributing to the advancement of falak through the use of their privately-owned observatories. Continuity of this falak knowledge can be perpetuated by them as they are also once commoners, who later got into astronomy through various means and own experience. Amateur observatories enable organizing of various activities to reveal falak science to the society. Activities such as observation of the night sky, eclipse, solar system objects and others can be arranged and this can attract the interest of the public to know and learn further the science of falak. Besides, amateur astronomer groups can have the role of contributing fruits of their labor especially in the field of astrophotography. In fact, many data and images of observed objects processed by this group of amateurs later became reference and collection of certain parties in carrying out studies. The recently concluded discussion entails that the role and contribution of amateur observatories are important to the advancement of falak in Malaysia.

The rooms and potentials for astronomy to grow in Malaysia are still vast. Still, much more effort is needed to attain a high level of knowledge to be at par with the international community. Among the efforts which can be done is to do more research on amateur observatories. This can motivate and fuel the spirit of this group of amateur astronomer to help in developing the science of falak. Their activities deserve to be appreciated and highlighted by relevant parties to encourage the growth of amateur observatories in Malaysia to a higher level as done by foreign countries. Therefore, it is this group of amateurs who can be the bridge to bring the Muslim community to explore space to a higher level in bringing back the glorious era of Islamic scientists.

\section{Acknowledgement}

This study is financed by the Research Group of Arabic Culture and Islamic Civilization (KUKAPI, DPP-2014-068), UKM; the Action/Strategic Research Project (PTS-2012-061; PTS-2012-124; PTS-2014-067; PTS-2014-068), UKM; the University-Industry Incentive Grant (SAKTI: INDUSTRI-2012-006), UKM; the Research Group of Modelling Interaction Between Civilisations (FRGS/1/2012/SSI05/UKM/02/1); and the Arus Perdana Project (AP-2012-001; AP-2013-017; AP2014-006), UKM.

\section{References}

Ahmad, S. (2011). Shahgazer Observatory-ahlan wa sahlan. Retrieved from http://www.falak-online.net/portalfalak/shahgazerobservatory-sgo-ahlan-wa-sahlan

Ahmad, S. (2012a). About me. Retrieved from http://www.falak-online.net/portalfalak/about-me

Ahmad, S. (2012b, February 8). Ideas and concepts of Shahgazer Observatory, Interview.

Aziz, A.H.A. (2010). Teknologi balai cerap: Dulu hingga kini [Observatory technology: Then and now]. Paper presented in Persidangan Hala Tuju Balai Cerap Semalaysia 2010 [The 2010 Pan-Malaysian Conference on Future Directions of Observatories]. Kepala Batas, Pulau Pinang.

Bahali, K. (2006, November 25). Kompleks Falak Al-Khawarizmi: Perancangan dan hala tuju [Al-Khawarizmi astronomy complex: Planning and future direction]. Paper presented in Seminar Penghayatan Falak 2006 [The 2006 Seminar on Appreciating Astronomy]. Malacca.

Bowler, S. (2011). Amateurs hit 20 million variable-star observations. Astronomy \& Geophysics, 52, 24-26.

Ford, D. (2011). Grepnova: a tool for supernova hunting. Journal of the British Astronomical Association, 121(6), 341-345. 
Groover, M. P. (2007). Automation, Production Systems and Computer-Integrated Manufacturing. n.pl.: Prentice Hall Publication.

Hadi, A.H. (2011). Ubah suai rumah jadi balai cerap [House renovation to turn it into an observatory]. Utusan Malaysia Archive. Retrieved from http://www.utusan.com.my/utusan/info.asp?y=2011\&dt=0804\&pub=Utusan_Malaysia\&sec=Sains_\%26_ Teknologi\&pg=st_01.htm

Hale, G.E. (1916). Work for the amateur astronomer. Publications of the Astronomical Society of the Pacific, 28(163), 53-61.

Hassan, A., Abiddin, N.Z. \& Ahmad, A.R. (2011). Islamic philosophy as the basis to ensure academic excellence. Asian Social Science, 7(3), 37-41. Retrieved from http://ccsenet.org/journal/index.php/ass/article/viewFile/7121/6976

Hicks, J. (2009). Building A Roll-Off Roof Observatory: A Complete Guide for Design and Construction. New York: Springer Science+Business Media Inc.

Holden, E.S. (1889). The work of an astronomical society. Publications of the Astronomical Society of the Pacific, 1(2), 9-20.

Ibrahim, I.A., Ahmad, M.R. \& Safiai, M.H. (2013). Astrofiqh observatories in Malaysia: A continuation of Islamic astronomy from West Asia. International Journal of West Asian Studies, 5(2), 35-50. Retrieved from http://www.ukm.my/ijwas/images/koleksi jurnal pdf/vol5_n2_2013a/3_Balai_Cerap_Astrofigh_di_Malaysia.pdf

Ibrahim, I.A., Ahmad, M.R., Safiai, M.H. \& Mujani W.K. (2012). Islamic astronomy and the establishment of al-Khawarizmi complex in Malaysia. Advances in Natural and Applied Sciences, 6(3), 316-320. Retrieved from http://www.aensiweb.com/old/anas/ 2012/316-320.pdf

Idris, H. (2012, February 24). Early history of hilal sighting in Malaysia, Interview.

Ismail, K., Nawawi, M.S.A.M., Yusuf, M.S.M. \& Niri, M.A. (2008, April 1). Peranan institusi balai cerap dalam pembangunan ketamadunan Islam: Satu sorotan [The role of observatory institutions in the development of Islamic civilization: A highlight]. Paper presented in Seminar Kebangsaan Kecemerlangan Tamadun Islam dalam Agro, Sains dan Teknologi [National Seminar on the Excellence of Islamic Civilization in Agriculture, Science and Technology]. Universiti Malaya, Kuala Lumpur.

Jabatan Kemajuan Islam Malaysia. (2011). Koordinat tempat cerapan rasmi di Malaysia [Coordinates of official observation sites in Malaysia]. Retrieved from http://apps.islam.gov.my/efalak/?q=en/erhk-tempat

Lattis, J. (review). (2011). The heavens on earth: observatories and astronomy in nineteenth-century science and culture. The Journal of the International Society for the History of Philosophy of Science, 1(1), 146-149.

Luna, E., Zazueta, S. \& Gutierrez, L. (2001). An innovative method for the alignment of astronomical telescopes. Publications of the Astronomical Society of the Pacific, 113(781), 379-384.

Majlis Raja-raja. (2010). Sejarah cerapan anak bulan [History of hilal sightings]. Retrieved from http://www.majlisrajaraja.gov.my/index.php/bm/profil/sejarah-cerapan-anak-bulan\#section=p1

Mujani, W.K., Ibrahim, I.A. \& Safiai, M.H. (2012). Observatories in Islamic history. Advances in Natural and Applied Sciences, 6(8), 13701373. Retrieved from http://www.aensiweb.com/old/anas/2012/1370-1373.pdf

Newcomb, S. (1881). Astronomical observatories. Science, 2(59), 377-380.

Observatori Negara Langkawi. (2009). Galeria Astronomi-Observatori Malaysia. Putrajaya: Agensi Angkasa Negara (ANGKASA).

Omar, M. (2006, November 25). Aktiviti falak sebagai aktiviti ko-kurikulum di sekolah menengah dan IPT [Falak activities as co-curricular activies at secondary schools and universities]. Paper presented in Seminar Penghayatan Falak 2006 [The 2006 Seminar on Appreciating Astronomy]. Malacca.

Omar, M. (2009). Peralatan mencerap [Observation equipment]. Retrieved from http://drrowi.blogspot.com/2010/03/peralatanmencerap.html

Omar, M. (2012a, January 17). Coordinates and location of Dr. Rowi's Mini Observatory, Kelantan, Interview.

Omar, M. (2012b). Filamen gergasi [Gigantic filaments]. Retrieved from http://drrowi.blogspot.com/2012/08/filamen-gergasi.html

Othman, M. (1993). Kepentingan balai cerap dalam penyelidikan astronomi [The importance of observatory in astronomy research]. Paper presented in Seminar Ilmu Falak Peringkat Kebangsaan 1414/1993 [National-Level Astronomy Seminar 1414H/1993AD]. Kuala Terengganu, Terengganu.

Peach, D. (2004). The ultimate location for amateur astronomy? Journal of the British Astronomical Association, 114(4), $188-192$.

Riva, M., Basso, S. \& Canestrari, R. (2012). An innovative alt-alt telescope for small observatories and amateur astronomers. Proceedings of the SPIE, 8444, 8444421-8444427.

Safiai, M.H., Jamsari, E.A. \& Ibrahim, I.A. (2014). Malaysian observatories and those of the Islamic civization era: General similarities. Middle-East Journal of Scientific Research, 20(12), 2164-2171. Retrieved from http://www.idosi.org/mejsr/mejsr20(12)14/90.pdf

Stuart, A.M. (2006). CCD Astrophotography: High-Quality Imaging from the Suburbs. New York: Springer Science+Business Media Inc.

Unit Falak Bahagian Penyelidikan. (2001). Kaedah Penentuan Awal Bulan Ramadan, Syawal dan Zulhijjah [Methods for Determining the Start of Ramadhan, Syawwal and Zulhijjah]. Putrajaya: Jabatan Kemajuan Islam Malaysia (JAKIM).

Vasiliev, S.A. \& Tataridou, V.N. (2013). The factual data on the celestial bodies influences in seismic activity. Applied Physics Research, 5(1), 36-50. Retrieved from http://ccsenet.org/journal/index.php/apr/article/view/23713/15076

Von Engelhardt, B. (1887). A model for amateur astronomers. Science, 9(224), 502.

Zainuddin, M.Z. (2010, June 28). Hala tuju balai cerap di Malaysia [Future direction of the observatories in Malaysia]. Paper presented in Persidangan Hala Tuju Balai Cerap Semalaysia 2010 [The 2010 Pan-Malaysian Conference on Future Directions of Observatories]. Kepala Batas, Pulau Pinang. 
Appendix A. Roof-top level of Dr. Rowi's house

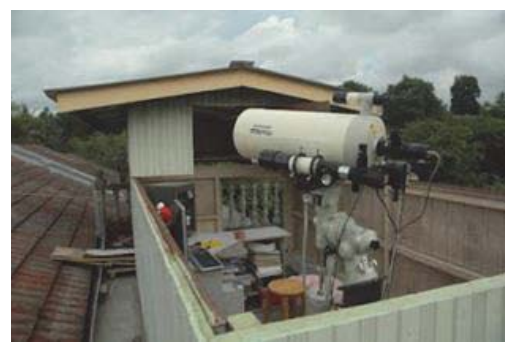

Source: http://drrowi.blogspot.com

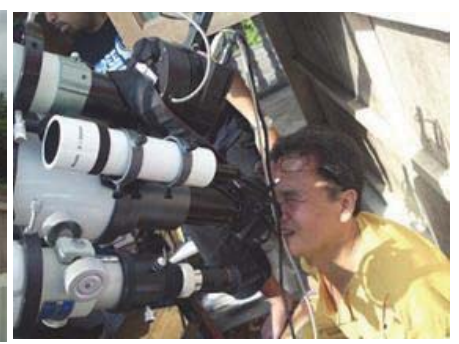

Source: http://drrowi.blogspot.com

Appendix B. Main telescope of Dr. Rowi's Mini Observatory

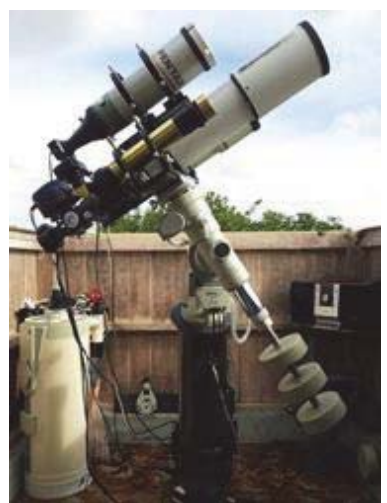

Source: http://drrowi.blogspot.com

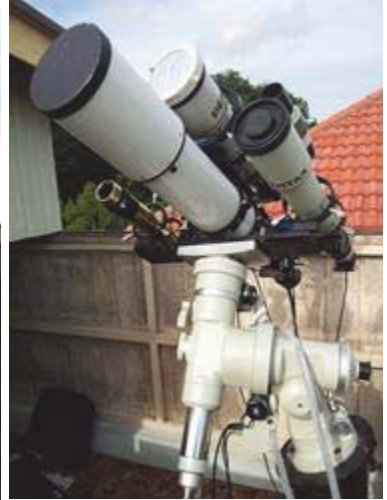

Source: http://drrowi.blogspot.com

Appendix C. Activities at Dr. Rowi's Mini Observatory

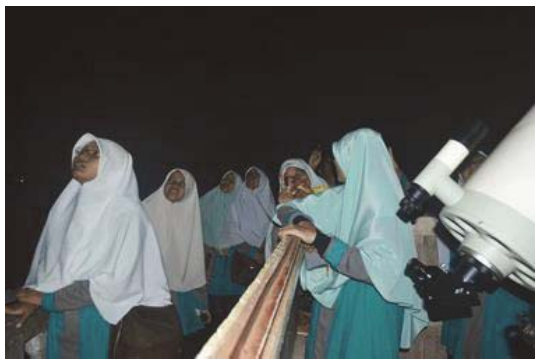

Source: http://drrowi.blogspot.com

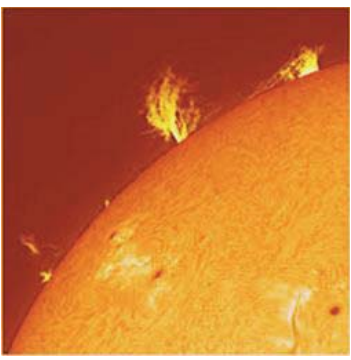

Source: http://drrowi.blogspot.com 
Appendix D. Roof section of Mr. Shahrin Ahmad's house

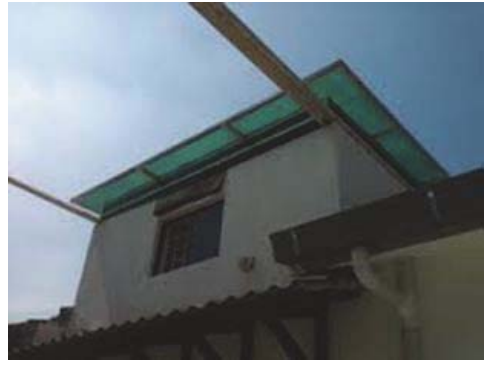

Source: http://falakonline.net/

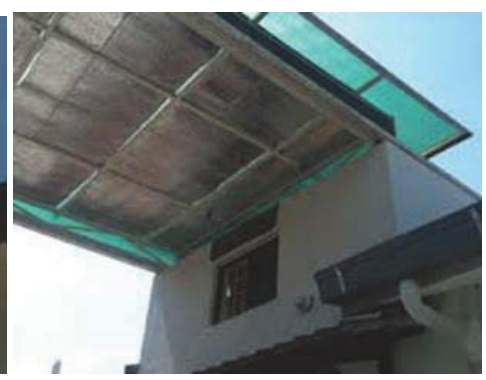

Source: http://falakonline.net/

Appendix E. Observatory equipment at SGO

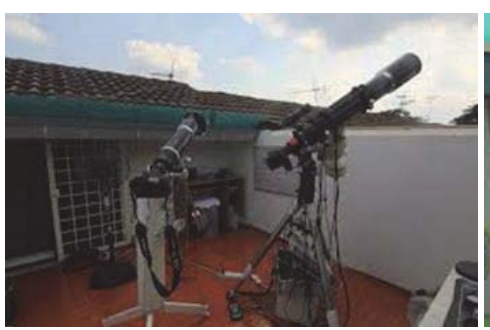

Source: http://falakonline.net/

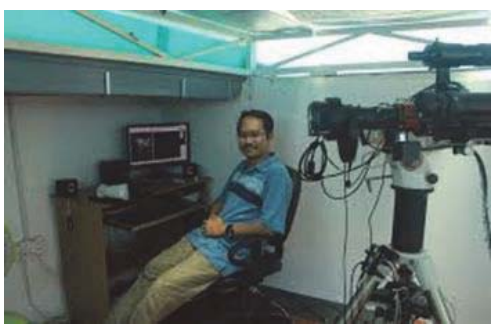

Source: http://falakonline.net/

Appendix F. Activities at SGO

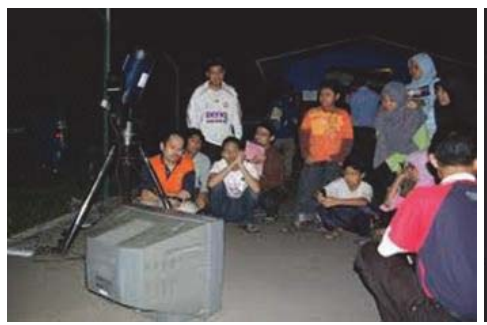

Source: http://falakonline.net/

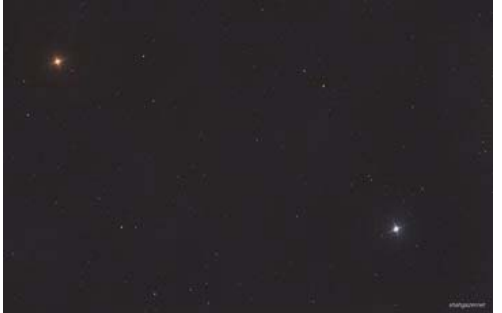

Source: http://falakonline.net/ 